\title{
Recenzja
}

\section{„Państwo Prawne”, nr 1 (1), czerwiec 2011 r., Czasopismo Prawnicze Wyższej Szkoły Zarządzania i Prawa im. Heleny Chodkowskiej w Warszawie, ss. 254}

Na rynku prawniczych periodyków ukazał się pierwszy numer „Państwa Prawnego", będący zarazem zwiastunem nowej wydawniczej inicjatywy Wyższej Szkoły Zarządzania i Prawa im. Heleny Chodkowskiej w Warszawie. Ambicją redaktorów jest publikacja rezultatów naukowego dorobku z zakresu prawa i administracji. Osoba redaktora naczelnego - prof. dr hab. Waldemara J. Wołpiuka, jak również skład Komitetu Redakcyjnego w osobach prof. dr hab. Jana Barcza, prof. dr hab. Andrzeja Biercia, prof. dr hab. Jerzego Kucińskiego, prof. dr hab. Jolanty Jakubowskiej - Hary oraz prof. dr hab. Stanisława Gebethnera, dostarczają gwarancji, że ambicje te będą realizowane na merytorycznie wysokim, naukowym poziomie, w czym techniczno-organizacyjnego wsparcia będzie udzielała Sekretarz Redakcji Joanna Paszkowska.

„Państwo Prawne” nie stanowi prostej kontynuacji „Zeszytów Prawniczych" - wcześniej wydawanych przez Uczelnię. Jak we wstępie do recenzowanego zeszytu zaznacza Rektor WSZiP dr Piotr Mochnaczewski, poprzednia formuła pisma okazała się niewystarczająca $\mathrm{w}$ świetle potrzeb wynikających z programu podnoszenia na wyższy poziom badań naukowych i związanego $\mathrm{z}$ tym doskonalenia programów nauczania, dalszego podnoszenia jakości nauczania oraz rozszerzenia działalności dydaktycznej szkoły o studia trzeciego stopnia. Periodyk zasadniczo został zaprojektowany jako możliwość prezentacji badawczego wysiłku Uczelni, ale jednocześnie jest on otwarty dla gości spoza murów WSZiP im. Heleny Chodkowskiej.

Za trafny uważam wybór tytułu czasopisma. Klauzulę demokratycznego państwa prawnego cechuje znacząca pojemność. Dodajmy, że klauzula ta posiada swój wymiar konstytucyjny. Niemniej periodyk, czego dowodzi skład autorski i złożona tematyka pierwszego numeru, nie został wyprofilo- 
wany wyłącznie pod kątem artykułu 2 Konstytucji RP i związanych z nim bogatych dokonań doktryny oraz odpowiedniego orzecznictwa Trybunału Konstytucyjnego. Przeciwnie, twórcy periodyku realizują założenie szersze, bardziej elastyczne, wychodząc ze słusznego założenia, że formuła demokratycznego państwa prawnego powinna przenikać cały porządek prawny. Zatem „Państwo Prawne” otwiera swe podwoje przed odpowiednio szeroką rzeszą autorów - prawników.

$\mathrm{Z}$ tym rozumowaniem koresponduje przedmiotowe zróżnicowanie artykułów zamieszczonych w pierwszym numerze periodyku. Ogółem artykułów jest 10, przy czym muszę przyznać, że niełatwym zadaniem byłoby wskazanie treściowego klucza, który miałby rządzić układem i kolejnością opublikowanych artykułów.

Połowa z nich dotyczy zagadnień z zakresu prawa konstytucyjnego. Do tej części zeszytu zaliczymy opracowania poświęcone powoływaniu egzekutywy w systemie rządów parlamentarnych (R. Małajny), sporowi o rozdział państwa i kościoła (J. Szymanek), zagadnieniom terminologicznym związanym ze skargą konstytucyjną podmiotów niebędących osobami fizycznymi (S. Witkowski), sejmowym komisjom śledczym w świetle rozwiązań normatywnych i praktyki (J. Kuciński, A. J. Madera) oraz dymisji Rady Ministrów w świetle Konstytucji RP z 1997 r. (B. Opaliński). Interesującym dopełnieniem „bloku” konstytucyjnego jest publikacja wyników forum badawczego, dotyczącego zasady zaufania do państwa i stanowionego przez nie prawa w świetle badań sondażowych (W. J. Wołpiuk, A. Pietruszewska).

Pozostała połowa to artykuły, których przedmiot jest zakotwiczony $\mathrm{w}$ prawie karnym materialnym i procesowym, prawie ubezpieczeniowym, prawie administracyjnym oraz $\mathrm{w}$ prawie cywilnym. Kolejno stanowią one o metodach badawczych prawa karnego (A. Wilkowska-Płóciennik), źródłach i charakterze prawa ubezpieczeń gospodarczych (E. Kędra), sposobach przedstawienia opinii przez biegłego wobec jej oceny przez organ procesowy (J. Żylińska), prawnych i administracyjnych aspektach ochrony zabytków i opieki nad nimi (W. L. Nowak) oraz cywilistycznym uwagom o istocie zrzeczenia się w prawie (J. Holocher).

Tak więc przy dominacji prezentacji zagadnień z zakresu prawa konstytucyjnego, udało się jednak w numerze pierwszym „Państwa Prawnego” przedstawić stosunkowo szeroką i zróżnicowaną paletę prawnych problemów. Rozumiem, że takie było założenie redaktorów zeszytu. 
Całości obrazu pierwszego numeru nowego periodyku dopełniają recenzje w liczbie czterech oraz dwa sprawozdania, w tym sprawozdanie z owocnego II Seminarium Młodych Badaczy Prawa Konstytucyjnego nt.: Systemy rzadów w państwach europejskich, Gdynia 5-7 października 2010 r. (A. Frankiewicz). Kolejne z cyklu tych seminariów jest szczególnie godne odnotowania jako forum wymiany myśli i doświadczeń młodszej generacji polskich konstytucjonalistów. Satysfakcją napawa, że seminaria te powoli stają się pewną tradycją i wpisują się w doroczne, krajowe kalendaria naukowych spotkań konstytucjonalistów.

Obok polskiego spisu treści zamieszczony został jego odpowiednik w języku angielskim. Do każdego artykułu załączono streszczenie w języku angielskim.

Andrzej Bisztyga (Uniwersytet Śląski) 